Оригинальная статья / Original article

УДК 577.124. $5: 579.66$

http://dx.doi.org/10.21285/2227-2925-2019-9-3-420-429

\title{
Study of the influence of Medusomyces gisevii Sa-12 inoculum dosage on bacterial cellulose yield and degree of polymerisation
}

\author{
(C) E.A. Skiba, O.V. Baibakova, E.K. Gladysheva, V.V. Budaeva
}

Institute for Problems of Chemical and Energetic Technologies of the SB RAS, Biysk, Russian Federation

\begin{abstract}
Bacterial cellulose (BC) consists in a highly crystalline nanopolymer whose potential for application in both traditional and new industries is significant due to its unique physico-mechanical properties. In scaled $B C$ biosynthesis processes, the use of microorganism consortia characterised by their adaptability and synergistic effects when coordinating substrate consumption appears to be promising. In the present work, the effect of inoculum dosage on BC yield during Medusomyces gisevii Sa-12 symbiotic culture on a glucose medium under optimal conditions is studied in detail. Two available methods were chosen for quality control of the BC: scanning electron microscopy, presenting an express method for confirming the origin of cellulose; and the degree of polymerisation in terms of a common method for controlling the quality of cellulose. Four experiments were carried out for the producer introduction with a dosage of 5, 10, 15 and $20 \%$ vol.. Use of the Medusomyces gisevii Sa-12 symbiotic culture provided the greatest number of acetic acid bacteria and the highest BC yield (7.5-8.0\%) with an inoculum dosage of 10-20\% vol. At the same time, an inoculum dosage of $20 \%$ vol. allowed the culture time to be halved, while an inoculum dosage of $5 \%$ vol. appears to be insufficient. All inoculum dosage variants were determined to provide the same three-dimensional cross-linked microfibrillar structure of BC samples. The degree of polymerisation (DP) of BC samples was first established to depend on the dosage of the inoculum and the duration of BC biosynthesis. Thus, the biosynthesis process can be controlled using such a simple parameter as inoculum dosage and BCs can be synthesised directionally with a given DP. The inoculum dosage of $10 \% \mathrm{vol}$. was established as providing the highest possible DP of BC (value of 5000), decreasing slightly during prolonged culture.
\end{abstract}

Keywords: inoculum dosage, Medusomyces gisevii Sa-12, biosynthesis, bacterial nanocellulose, bacterial cellulose yield, degree of polymerization

Acknowledgments: The research was supported by the Russian Science Foundation (project №17-19-01054).

Information about the article: Received May 31, 2019; accepted for publication September 5, 2019; available online September 30, 2019.

For citation: Skiba E.A., Baibakova O.V., Gladysheva E.K., Budaeva V.V. Study of the influence of Medusomyces gisevii Sa-12 inoculum dosage on bacterial cellulose yield and degree of polymerisation. Izvestiya Vuzov. Prikladnaya Khimiya i Biotekhnologiya [Proceedings of Universities. Applied Chemistry and Biotechnology]. 2019, vol. 9, no. 3, pp. 420-429. (In Russian). DOI: 10.21285/2227-2925-2019-9-3-420-429

\section{Исследование влияния дозировки инокулята Medusomyces gisevii Sa-12 на выход и степень полимеризации бактериальной целлюлозы}

\author{
( Е.А. Скиба, О.В. Байбакова, Е.К. Гладышева, В.В. Будаева \\ Институт проблем химико-энергетических технологий СО РАН, г. Бийск, Российская Федерация
}

Резюме: Бактериальная целлюлоза (БЦ) является высококристаллическим нанополимером с уникальными фризико-механическими свойствами, поэтому обладает превосходным потенциалом применения как в традиционных, так и в новых отраслях. В маситабированных процессах биосинтеза БЦ перспективно применение консорциумов микроорганизмов, характеризующихся адаптивностью и обла- 
дающих синергетическими эфрфектами в координирующем потреблении субстрата, поэтому $в$ данной работе используется симбиотическая культура Medusomyces gisevii Sa-12. В работе подробно исследуется влияние дозировки инокулята на выход БЦ при культивировании на глюкозной среде в оптимальных условиях. Для контроля качества БЦ выбрано два доступных метода: растровая электронная микроскопия, которая является экспресс-методом подтверждения происхождения целлюлозы и степень полимеризации, как распространённый метод контроля качества целлюлозы. Проведено четыре эксперимента с внесением продуцента с дозировкой 5\% об., $10 \%$ об., 15\% об. и $20 \%$ об. Выявлено что, при использовании симбиотической культуры Medusomyces gisevii Sa-12 наибольшая численность уксуснокислых бактерий и наибольший выход БЦ (7,5-8,0\%) обеспечиваются при дозировке инокулята 10-20\% об. При этом дозировка инокулята 20\% об. позволяет сократить продолжительность культивирования вдвое. Дозировка инокулята 5\% об. является недостаточной. Показано, что все варианты дозировки инокулята обеспечивают одинаковое трехмерное сетчатое микрофиибиллярное строение образцов БЦ. Впервые установлено, что степень полимеризации (СП) образцов БЦ зависит от дозировки инокулята и продолжительности биосинтеза БЦ. Таким образом, с помощью простого параметра - дозировки инокулята - можно управлять процессом биосинтеза и направленно синтезировать БЦ с заданной СП. Установлено, что дозировка инокулята $10 \%$ об., обеспечивает получение максимально высокой СП БЦ - 5000, которая при длительном культивировании снижается незначительно.

Ключевые слова: дозировка инокулята, Medusomyces gisevii Sa-12, биосинтез, бактериальная целлюлоза, выход, степень полимеризации

Благодарности: Исследование выполнено за счет гранта Российского научного фонда (проект № 17 19-01054).

Информация о статье: Дата поступления 31 мая 2019 г.; дата принятия к печати 5 сентября 2019 г.; дата онлайн-размещения 30 сентября 2019 г.

Для цитирования: Скиба Е.А., Байбакова О.В., Гладышева Е.К., Будаева В.В. Исследование влияния дозировки инокулята Medusomyces gisevii Sa-12 на выход и степень полимеризации бактериальной целлюлозы // Известия вузов. Прикладная химия и биотехнология. 2019. T. 9, N 3. C. 420-429. DOI: 10.21285/2227-2925-2019-9-3-420-429

\section{INTRODUCTION}

Bacterial cellulose $(B C)$ manifests itself as a unique polymer having a three-dimensional crosslinked structure formed by pure cellulose nanofibers synthesised by microorganisms. Compared with plant cellulose, $\mathrm{BC}$ is characterised by its chemical purity, porosity, higher degree of crystallinity and polymerisation, as well as high moisture retaining ability. In addition, BC is a biodegradable, biocompatible and non-toxic biopolymer having unique physical and mechanical properties, such as extraordinary mechanical strength, permeability to liquids and gases, flexibility and formability [1]. The combination of these properties determines an extremely wide range of $\mathrm{BC}$ applications: these include pulp and paper and textile industries, food industry, cosmetology, pharmaceuticals, biomedicine and innovative engineering materials (diaphragms for acoustic systems, flexible touch displays, electrically conductive nanocomposite membranes, etc.) [2-5].

The potential widespread use of $\mathrm{BC}$ is hindered by its high cost, due to the low yield determined by the characteristics of the metabolism of cellulosesynthesising bacteria. Therefore, studies aimed at increasing the yield of $\mathrm{BC}$ are relevant. These include screening of carbon sources, nitrogen and stimulating additives, optimisation of the composition of nutrient media, a detailed study of culture condi- tions, innovative engineering support of the biosynthesis process and the search for new producers and their gene modifications $[1,2,6]$.

Medusomyces gisevii Sa-12 symbiotic culture is used in this study. This culture can be termed "underestimated", since, although it has often been used as a source for isolating individual strains of cellulose-synthesising bacteria [1-7], it has rarely been used as an independent producer [2, 8-10]. This is associated with an obvious fact: in the microorganism community, part of the substrate is spent on the vital activity of non-target microorganisms and the biosynthesis of their metabolites. However, there have been several reports concerning the difficulties of scaling the BC biosynthesis process and modifying it for use in complex industrial environments using individual genetically modified strains and the consortia advantages. The latter include adaptability and synergistic effects in coordinating substrate consumption in consortia, which provides their adaptation to changing environmental conditions during biosynthesis and maintenance of the process productivity at a high level $[1,2,11]$.

The main parameters of the Medusomyces gisevii Sa-12 culture on glucose media were described by us in [9]. However, such an important parameter as the inoculum dosage remained unexplored. BC synthesis is known to be stimulated 
when the cell count increases and the cells go into a quorum-sensing state $[12,13]$. In order to avoid reverse inhibition, it is necessary to ensure the stable functioning of highly concentrated populations. A possible solution to this problem is proposed in the form of slow growing or non-growing cell populations, which is achieved by immobilising producer cells in $\mathrm{BC}$ biosynthesis. In this case, both a negative immobilisation result for the Acetobacter xylinum ATCC 700178 strain [14] and a positive result for Komagataeibacter xylinum B-12429 strain [15] are described in the literature. Before carrying out such complex studies, the optimum inoculum dosage for the used culture should be determined, since the results achieved with varying dosages can differ greatly.

A review of the relevant literary sources connected with the aim of this study showed a lack of data on the effect of the inoculum dosage of the Medusomyces gisevii Sa-12 symbiotic culture on the $\mathrm{BC}$ yield. Two available methods were chosen for quality control of the BC: scanning electron microscopy, presenting an express method for confirming the origin of cellulose [1, 2] and the degree of polymerisation in terms of a common method for controlling the quality of cellulose [16-18]

\section{EXPERIMENTAL PART}

BC biosynthesis was conducted on a semisynthetic glucose medium using a Medusomyces gisevii Sa-12 symbiotic culture as inoculum in $250 \mathrm{~mL}$ containers with a spacing factor of $80 \%$. The viability of the Medusomyces gisevii Sa-12 producer was maintained by subculturing every 14 days on a synthetic glucose medium prepared by dissolving glucose $(22 \mathrm{~g} / \mathrm{L})$ in black tea extract (the content of dry tea in the nutrient medium was $5 \mathrm{~g} / \mathrm{L}$, corresponding to $1.6 \mathrm{~g} / \mathrm{L}$ of extractives according to [9]). The resulting solution was filtered and cooled to a temperature of $27^{\circ} \mathrm{C}$, then a symbiotic culture was introduced.

In order to study the effect of the inoculum quantity on the yield of $\mathrm{BC}$ and its physicochemical characteristics, four experiments were carried out

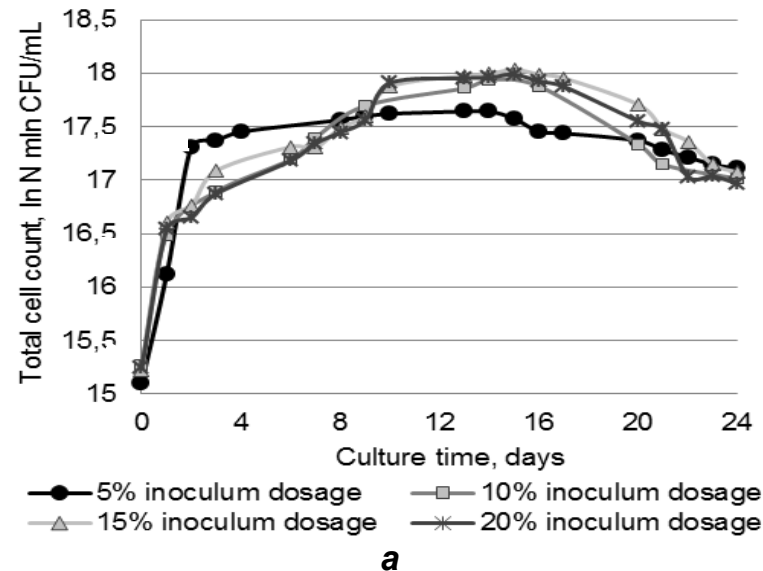

with the producer introduced into the nutrient medium at the following dosages: $5,10,15$ and $20 \%$ vol. For each dosage, BC biosynthesis was carried out for 24 days under static conditions in a TC-80 dry-air thermostat at a temperature of $27^{\circ} \mathrm{C}$ accompanied by daily monitoring the total cell count, glucose concentration, $\mathrm{pH}$ and $\mathrm{BC}$ yield. The obtained $\mathrm{BC}$ samples were purified from residues of the nutrient medium and cells by passive diffusion in dilute solutions of sodium hydroxide and hydrochloric acid according to [9]. In order to determine the BC yield, the films were dried at room temperature in the expanded state. The yield of $\mathrm{BC}$ was calculated as the ratio of the mass of dry $B C$ and the mass of glucose in the volume of the nutrient medium [9, 19-21].

The total count of yeast cells and acetic acid bacteria was determined by the limiting dilution method. The yeast count was controlled by inoculation on an agar medium of unhopped beer wort (culture at $27^{\circ} \mathrm{C}$ for 3 days). The count of acetic acid bacteria was controlled by inoculation on yeast-agar with $3 \%$ (vol.) of ethanol (culture at $27^{\circ} \mathrm{C}$ for 3 days). Glucose concentration in the nutrient medium was established spectrophotometrically using a reagent based on 3,5-dinitrosalicylic acid (Panreac, Spain) by UNICO UV-2804 instrument (USA). The calculation of the substrate utilisation constant was performed according to [22]. The DP for the obtained BC samples was determined by a method based on the dissolution of cellulose in a cadoxene solution and subsequent viscometry of the resulting solution [23]. The microfibrillar structure of the BC was studied using a JSM-840 scanning electron microscope (Japan) [24].

The studies were carried out using the equipment of the Biysk Regional Centre for Collective Use SB RAS (IPCET SB RAS, Biysk).

\section{RESULTS AND DISCUSSION}

During the culture of Medusomyces gisevii Sa12 with a different dosage of the inoculum, the total count of yeast cells and acetic acid bacteria was determined. The results are presented in Fig. 1.

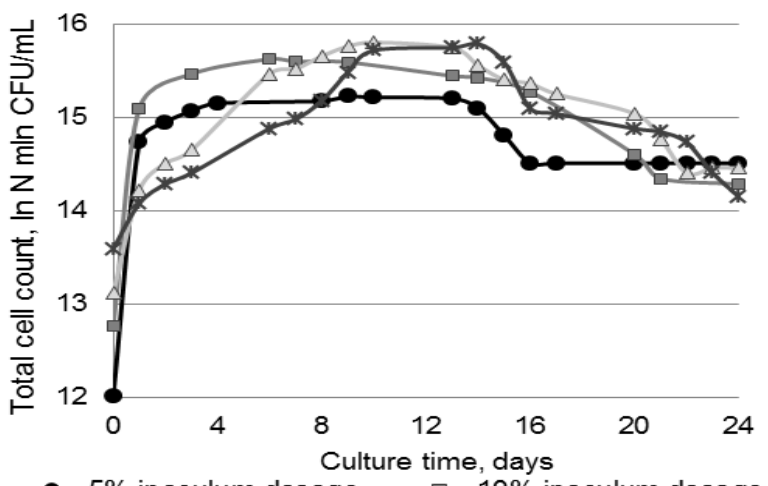

$\longrightarrow 5 \%$ inoculum dosage $\rightarrow-10 \%$ inoculum dosage $\triangle 15 \%$ inoculum dosage $\rightarrow-20 \%$ inoculum dosage

b

Fig. 1. Total cell count of (a) yeast and (b) acetic bacteria during the culture of Medusomyces gisevii Sa-12 with different inoculum dosage

Рис. 1. Общая концентрация клеток дрожжей (a) и уксуснокислых бактерий (b) в процессе культивирования Medusomyces gisevii Sa-12 с различной дозировкой инокулята 
For all inoculum introduction variants, the count for yeast cells in the nutrient medium during the culture of Medusomyces gisevii Sa-12 was determined to be an order of magnitude higher than for acetic acid bacteria. This appears to be characteristic of this symbiotic culture: yeast processes glucose into ethanol, further ethanol is consumed by acetic acid bacteria, while the bacteria synthesise $\mathrm{BC}$ gel-film to protect themselves from the environment. Thus, the metabolic elements of the symbiotic culture are localised in different partners, promoting the increase in the adaptability and stability of the culture [25].

The low inoculum dosage $5 \%$ vol. leads to a sharp increase in the specific cell growth rate: on the $2^{\text {nd }}$ day of culture, the yeast count is the highest among all variants and comprises $33 \mathrm{mln}$. CFU/mL, while the number of acetic acid bacteria is equal to $3.1 \mathrm{mln}$. CFU/mL, exceeding their number for inoculum dosages of 15 and $20 \%$ vol. However, already by the 5th day, both types of microorganisms go into the stationary phase and from $14^{\text {th }}$ day the death phase is observed.

According to the yeast count, the inoculum dosage variants of $10-20 \%$ vol. practically coincide: the exponential growth phase is observed for 2 days, then the linear and slow growth phases are presented; on the $10^{\text {th }}$ day, the cultures enter the stationary growth phase; the death phase is observed from the $18^{\text {th }}$ day. According to the count of acetic acid bacteria, the inoculum dosage of $10 \%$ vol. is in the lead. The culture enters the stationary phase on the $3^{\text {rd }}$ day with a bacterium count equal to $5.2 \mathrm{mln}$. CFU $/ \mathrm{mL}$; the death phase begins on the $16^{\text {th }}$ day. At inoculum dosages of 15 and $20 \%$ vol., the stationary phase is observed from the $10^{\text {th }}$ to the $16^{\text {th }}$ day. During this period the acetic acid bacteria count is slightly higher than for the inoculum dosage of $10 \%$ vol.: 7.3 and $6.7 \mathrm{mln}$. CFU $/ \mathrm{mL}$, respectively, against $5.9 \mathrm{mln}$. CFU/mL. The death phase also starts on the $16^{\text {th }}$ day.

Earlier, the count of acetic acid bacteria for the Medusomyces gisevii Sa-12 culture was shown by us to serve as a marker for $\mathrm{BC}$ synthesis: the higher the bacteria count, the higher the yield of $\mathrm{BC}$ [9], which demonstrates good agreement with the dependence of the $\mathrm{BC}$ biosynthesis on the acetic bacteria count for individual strains [12, 13]. Thus, for inoculum dosages from 10 to $20 \%$ vol., an equivalent high yield should be obtained and the inoculum dosage of $5 \%$ vol. turns out to be clearly insufficient: no proper cell count is provided in the medium, predicting low $\mathrm{BC}$ yield for this variant.

Fig. 2 shows glucose utilisation and BC yield during culture of Medusomyces gisevii Sa-12 depending on the dosage of the inoculum.

It can be seen from the presented data, that, with an increase in the inoculum dosage, the process of substrate utilisation is intensified: the substrate utilisation constant comprises 0.193 and 0.229 days $^{-1}$ for the inoculum dosage of 5 and $20 \%$ vol., respectively. For all the inoculum dosage variants, the main glucose consumption occurred from 0 to 10 days, due to its consumption by microorganism cells and their reproduction. This period corresponds to the logarithmic growth phase of yeast and acetic acid bacteria (Fig. 1A). After 10 days, a slow utilisation of the substrate was observed for the reason of obvious glucose consumption for the metabolism of maintaining microorganisms.

When the inoculum was added in an amount of $5 \%$ (vol.) of the nutrient medium volume, a thin gel film of BC was formed only on the $8^{\text {th }}$ day of culture. In this variant, the $\mathrm{BC}$ growth process took place in three stages: from $8^{\text {th }}$ to $10^{\text {th }}$ day, the yield increased to $2.3 \%$; from $10^{\text {th }}$ to $21^{\text {st }}$ day, a plateau is observed on the chart; from $21^{\text {st }}$ to $24^{\text {th }}$ day, a further increase in $\mathrm{BC}$ growth to $6.9 \%$ is presented.

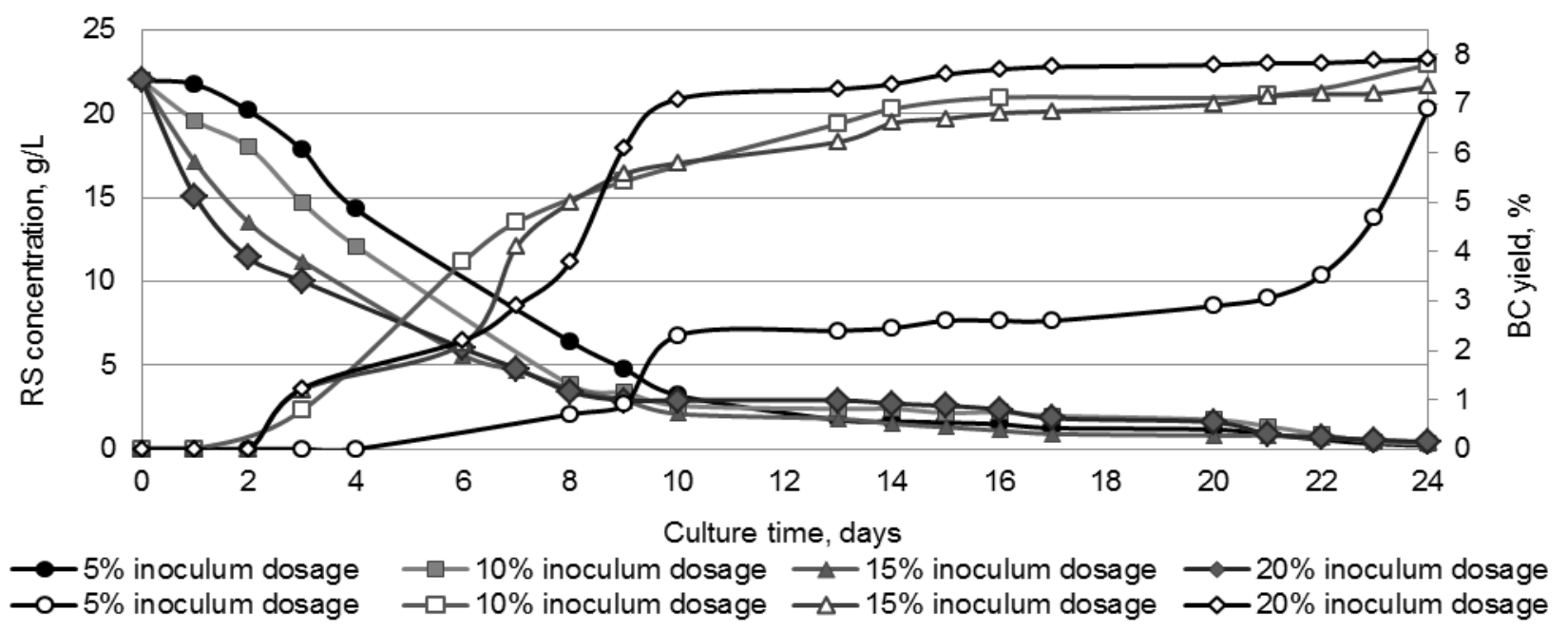

Fig. 2. Glucose concentration and BC yield plotted against inoculum dosage

Рис. 2. Изменение концентрации глюкозы и выхода БЦ в зависимостиот дозировки инокулята 
This can be explained by the formation of new thin $\mathrm{BC}$ layers on the surface of the culture medium with new generations of acetic acid bacteria. For inoculum dosages of $10 \%$ vol. and $15 \%$ vol., the curves demonstrate an exponential character, reaching a plateau in about 16 days. After this, a very slow increase in $B C$ is observed. At an inoculum dosage of $20 \%$ vol., the main increase equal to $7.1 \%$ in $\mathrm{BC}$ yield occurred from $3 \mathrm{rd}$ to 10th day of culture. In the period from 10th to 24th day, a slow increase in the yield of $B C$ is presented and no visible degradation processes are observed. After 24 days of culture, for inoculum dosage of 10,15 and $20 \%$ vol., the BC yield comprised $7.8,7.4$ and $7.9 \%$, respectively. Based on Fig. 2, the inoculum dosage of $5 \%$ vol. can be concluded to be insufficient for Medusomyces gisevii Sa-12: at this dosage, glucose is spent on the synthesis for biomass of both yeast and acetic acid bacteria and their high specific growth rates lead to inhibition of $\mathrm{BC}$ biosynthesis.

The data presented in the literature indicate that, for various producers, the quantity of inoculum providing the highest $\mathrm{BC}$ yield can vary in the range from 5 to $20 \%$ vol. For example, in [26], the effect of inoculum dosages of 10,20 and $30 \%$ vol. on the $\mathrm{BC}$ yield was described using a Komagataeibacter hansenii ATCC 23769 producer with the maximum obtained at $20 \%$ vol. dosage. A study of the effect of inoculum dosage ranging from 4 to $12 \%$ vol. using a Gluconacetobacter xylinum ATCC 10245 producer showed that the maximum $B C$ yield is
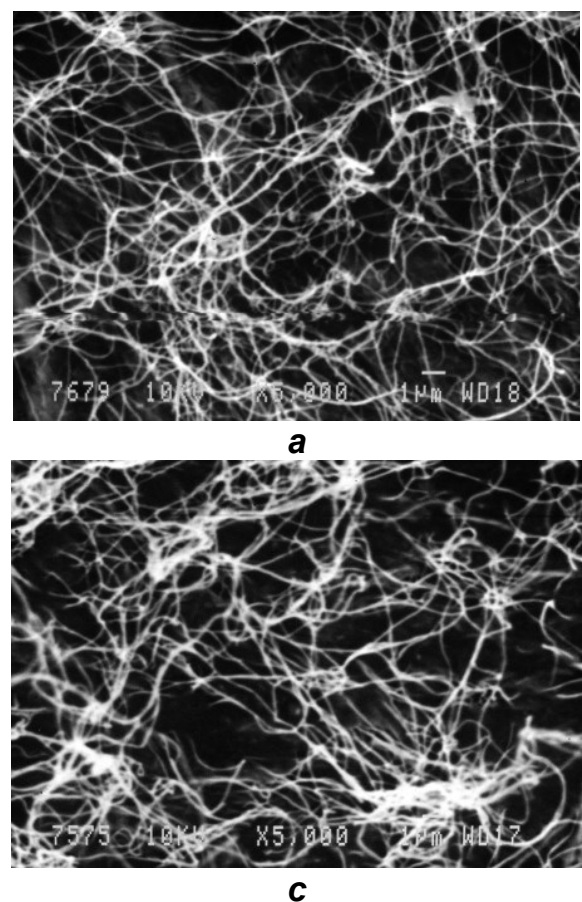

obtained at $8 \%$ vol. of inoculum [27]. For Gluconacetobacter sp. RV28 producer tested in the range from 1 to $10 \%$ vol. the inoculum dosage providing maximum yield was $5 \%$ (vol.). Here, both a decrease and an increase in the indicated inoculum dosage was observed to result in a decrease in BC yield [28]. For the Gluconacetobacter xylinus $\mathrm{CH} 001$ producer, over the range of $4-12 \%$ vol., an inoculum dose of $10 \%$ vol. turned out to be optimal [29].

In our case, for the Medusomyces gisevii Sa-12 symbiotic culture, the application of inoculum dosages from 10 to $20 \%$ vol. provides comparable results. With a view to economy, a dosage of $10 \%$ vol. is recommended. If the problem consists in accelerating $\mathrm{BC}$ biosynthesis, it is recommended to use a dosage of inoculum of $20 \%$ vol. as this will reduce the time of culture by 2 times.

Fig. 3 demonstrates SEM images of BC samples. For all variants of inoculum dosages, BC samples were obtained with an unordered threedimensional network structure and microfibril thickness from 30 to $70 \mathrm{~nm}$, which is characteristic of BCs, fundamentally distinguishing it from all other types of celluloses and being in good agreement with published data [2, 10, 30]. According to SEM, no differences between the samples were revealed; thus, it can be concluded that inoculum dosage has no effect on the microfibrillar structure of the BC.]

The effect of inoculum dosage and culture time on the degree of cellulose polymerisation in $\mathrm{BC}$ samples is shown in Fig. 4.

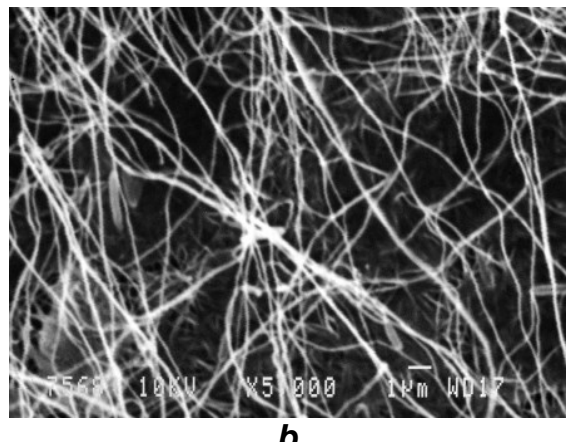

b

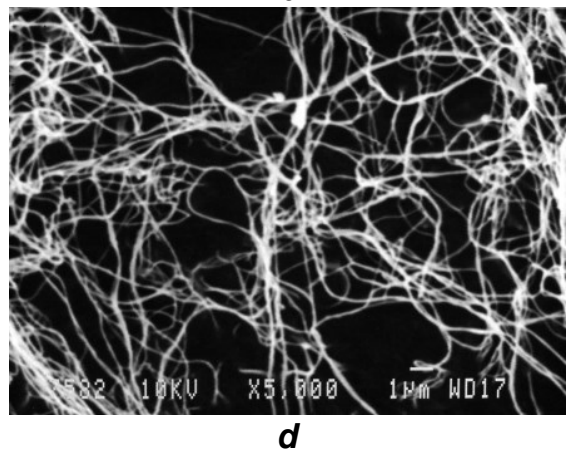

Fig. 3. SEM image of BC samples at different inoculum dosage: $a-5 \% ; b-10 \% ; c-15 \% ; d-20 \%$; (zoom $\times 5000)$

Рис. 3. Микрофотографии образцов БЦ при различной дозировке инокулята, PЭМ, \%: a - 5; b - 10; c - 15; d- 20; (масштабирование × 5000) 


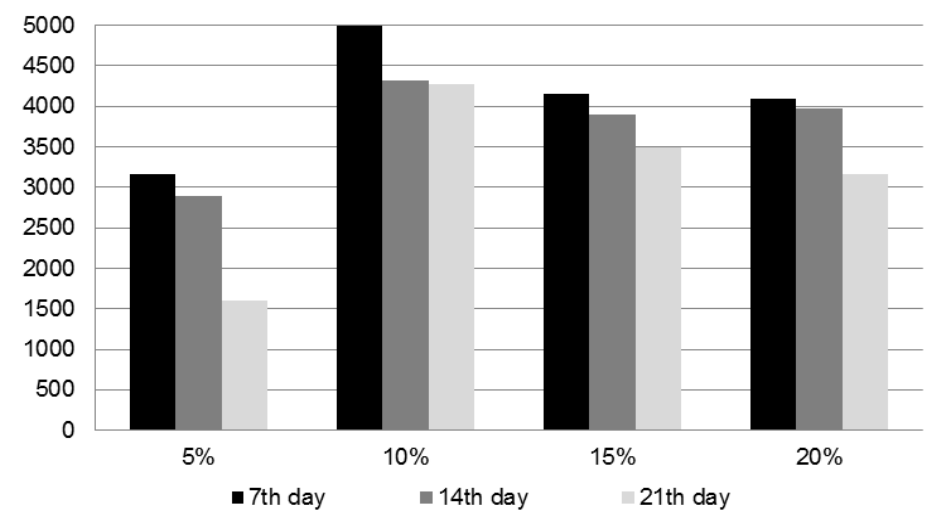

Fig. 4. Effects of inoculum dosage and culture time on cellulose polymerisation degree of $B C$ samples

\section{Рис. 4. Влияние дозировки инокулята и продолжительности культивирования на степень полимеризации целлюлозы в образцах БЦ}

For all types of experiments, on the $7^{\text {th }}$ day of biosynthesis, high DP values (3160-5000) for BCs, typical for BC, were obtained. The DP obtained in our work are in good agreement with the literature data, where, for various $\mathrm{BC}$ producers, it varies from 1600 to 6000 [17, 18, 31, 32].

From the data analysis (Fig. 4), it follows that the maximum value of the cellulose DP, equal to 5000 , was reached on the $7^{\text {th }}$ day of $\mathrm{BC}$ biosynthesis at a inoculum dosage of $10 \%$ vol. Dosages of 15 and $20 \%$ vol. demonstrated very similar results in terms of DP value: 4150 and 4100 , respectively. For the $5 \%$ vol. of inoculum, the smallest DP value of 3160 was observed, which is 1.6 times lower than for the $10 \%$ vol. dosage. The results can be explained by the metabolic characteristics of the Medusomyces gisevii Sa-12 symbiotic culture: low inoculum dosage leads not only to inappropriate consumption of the substrate for biomass synthesis, instead of $\mathrm{BC}$ synthesis, but also to a decrease in the quality of the synthesised BC.

For all variants, a decrease in the DP of cellulose occurs with an increase in the duration of biosynthesis from 7 to 21 days. Moreover, the decrease comprised 49.4, 14.6, 15.7 and $22.9 \%$ (of the maximum DP value for this variant on the 7 th day of biosynthesis) for dosages of $5,10,15$ and $20 \%$ vol., respectively. Therefore, in order to reduce the DP during the $\mathrm{BC}$ biosynthesis, the dosage of the inoculum of $5 \% \mathrm{vol}$. is concluded to be insufficient; conversely, a dosage of $20 \%$ vol. is excessive.

The decrease of DP during biosynthesis may be due to the fact that, in the first 7 days of culture, biosynthesis of highly polymerised $\mathrm{BC}$ takes place and, after culture from 7 days onwards, low polymerised BC layers are synthesised, which reduces the average cellulose DP value in BC samples. Physiologically, this version is explained by a well-known fact: since acetic acid bacteria are strict aerobes, the biosynthesis of new BC layers is carried out on the surface of already formed layers [1, 2]. However, over time, the state of the population worsens: nutrients are exhausted, metabolic products are accumulated promoting for the decrease in DP of the synthesised BC. The tendency toward a decrease in the degree of polymerisation of cellulose with an increase in the culture time is described in [18]; however, the authors simply state the fact without being able to adequately explain it. It should be noted that problems of long-term BC culture in global practice have been poorly studied, despite the desirability for the duration of this process to be reduced. In our opinion, the stated version of the decrease in DP is more viable than the version of the decrease in DP explained by the destruction of $\mathrm{BC}$ during long-term culture proposed in the 1970s [33] since the total mass of BC during prolonged culture continues to increase.

Thus, in the process of studying the inoculum dosage, we were able to observe an interesting regularity of the dependency of the DP of BC samples on the inoculum dosage and the duration of $\mathrm{BC}$ biosynthesis, as well as to determine the optimal inoculum dosage of $10 \%$ vol., leading to the procurement of a $\mathrm{BC}$ possessing maximum DP that decreases slightly during long-term culture. This opens up the possibility of regulating the biosynthesis of $\mathrm{BC}$ to directly obtain $\mathrm{BC}$ having desired properties.

\section{CONCLUSIONS}

As the result of this study, during biosynthesis of $\mathrm{BC}$ by the Medusomyces gisevii Sa-12 symbiotic culture, a high yield (7.5-8.0\%) was established for an inoculum dosage of $10-20 \%$ vol. Moreover, in the case of an inoculum dosage of $20 \%$ vol., the culture time is reduced by half.

All inoculum dosage variants are shown to provide the same three-dimensional cross-linked microfibrillar structure of BC samples. 
For the first time, the dependence of the $\mathrm{BC}$ polymerisation degree on the inoculum dosage and the time of biosynthesis has been established.
The optimal dosage of the inoculum $10 \%$ vol. was determined, resulting in a maximum degree of polymerisation equal to 5000 .
1. Campano C., Balea A., Blanco A., Negro C. Enhancement of the fermentation process and properties of bacterial cellulose: a review. Cellulose. 2016, vol. 23, pp. 57-91. https://doi.org/10.1007/s10570-015-0802-0

2. Gama M., Dourado F., Bielecki S. Bacterial nanocellulose. From Biotechnology to Bio-Economy. Amsterdam: Elsevier, 2016, 240 p.

3. Revin V.V., Klenova N.A., Belousova Z.P., Red'kin N.A., Tukmakov K.N., Markova Yu.A., Sosova E.Yu. Production and studying properties of composites based on bacterial cellulose and poly- $\mathrm{N}$, $\mathrm{N}$-dimethyl-3,4-methylenpirrolidine chloride. Izvestiya vuzov. Prikladnaya khimiya i biotekhnologiya. 2017, vol. 7, no. 1, pp. 103-111. (In Russian). DOI: 10.212 85/2227-2925-2017-7-1-103-111

4. Barud H.G., Barud H.S., Gutierrez J., Silva R.R., Tercjak A., Lustri W.R., Ribeiro S. JL. A multipurpose natural and renewable polymer in medical applications: Bacterial cellulose. Carbohydrate Polymers. 2016, vol. 153, pp. 406-420. https://doi.org/10.1016/j. carbpol.2016.07.059

5. Mohite B.V., Koli S.H., Patil S.V. Bacterial Cellulose-Based Hydrogels: Synthesis, Properties, and Applications. In: Cellulose-Based Superabsorbent Hydrogels. Polymers and Polymeric Composites: A Reference Series. Ed. by M. Mondal. Springer, Cham. 2019, pp. 1255-1276. https://doi.org/10.1007/978-3319-77830-3_2

6. Suresh S. Biosynthesis and Assemblage of Extracellular Cellulose by Bacteria. In: Handbook of Environmental Materials Management. Ed. by C. Hussain. Springer, Cham. 2018, pp. 1-43. https://doi.org/ 10. 1007/978-3-319-58538-3_71-1

7. Shidlovskiy I.P., Shümilova A.A., Shishatskaya E.I., Volova T.G. Properties of Bacterial Cellulose Composites with Silver Nanoparticles. Biophysics. 2018, vol. 63, no. 4, pp. 519-525. https://doi.org/ 10.1134/S0006350918040188

8. Rogozhin V.V., Rogozhin Yu.V. Influence of anaerobic conditions on productivity of Medusomyces gisevii. Izvestiya vuzov. Prikladnaya khimiya $i$ biotekhnologiya. 2018, vol. 8, no. 1, pp. 59-66. (In Russian). DOI: 10.21285/2227-2925-2018-8-1-59-66

9. Gladysheva E.K., Skiba E.A., Zolotukhin V.N., Sakovich G. V. Study of the Conditions for the Biosynthesis of Bacterial Cellulose by the Producer Medusomyces gisevii Sa-12. Applied Biochemistry and Microbiology. 2018, vol. 54, no. 2, pp. 179-187. DOI: 10.1134 / S0003683818020035

10. Goh W.N., Rosma A., Kaur B., Fazilah A., Karim A.A, Rajeev B. Microstructure and physical properties of microbial cellulose produced during fermentation of black tea broth (kombucha). II. International Food Research Journal. 2012, vol. 19 (1), pp. 153-158.

11. Krystynowicz A., Czaja W., Wiktorowska-Jezi- erska A., Gonc M., Gonsalves-Mis kiewicz M., Turkiewicz M., Bielecki S. Factors affecting the yield and properties of bacterial cellulose. Journal of Industrial Microbiology and Biotechnology. 2002, vol. 29, no. 4, pp. 189-195. https://doi.org/10.1038/sj.jim.7000303

12. Römling U., Galperin M.Y. Bacterial cellulose biosynthesis: Diversity of operons, subunits, products, and functions. Trends in Microbiology. 2015, vol. 23, pp. 545-557. DOI: 10.1016/j.tim.2015.05.005

13. Borzani W., Souza S.J. Mechanism of the film thickness increasing during the bacterial production of cellulose on non-agitated liquid media. Biotechnology Letters. 1995, vol. 17, no. 11, pp. 1271-1272. https://doi.org/10.1007/BF00128400

14. Cheng K.C., Catchmark J.M., Demirci A. Enhanced production of bacterial cellulose by using a biofilm reactor and its material property analysis. Journal of Biological Engineering. 2009, vol. 3, pp. 12. https://doi.org/10.1186/1754-1611-3-12

15. Stepanov N., Efremenko E. "Deceived" Concentrated Immobilized Cells as Biocatalyst for Intensive Bacterial Cellulose Production from Various Sources. Catalysts. 2018, vol. 8, no. 1, pp. 33. https://doi.org/10.3390/catal8010033

16. Valls C., Pastor F.I.J., Roncero M.B., Vidal T., Diaz P., Martínez J., Valenzuela S.V. Assessing the enzymatic effects of cellulases and LPMO in improving mechanical fibrillation of cotton linters. Biotechnology for Biofuels. 2019, vol. 12, pp. 161. https://doi.org/ 10.1186/s13068-019-1502-z

17. Zugenmaier P. Crystalline Cellulose and Derivatives: Characterization and Structures, Springer Series in Wood Science. Springer-Verlag Berlin Heidleberg, 2008, $285 \mathrm{p}$.

18. Shi Q.S., Feng J., LiW.R., Zhou G., Chen A.M., Ouyang Y.S., Chen Y.B. Effect of different conditions on the average degree of polymerization of bacterial cellulose produced by Gluconacetobacter Intermedius BC-41. Cellulose Chemistry and Technology. 2013, vol. 47, pp. 503-508.

19. Hestrin S., Schramm M. Synthesis of cellulose by Acetobacter xylinum: II. Preparation of freeze-dried cells capable of polymerizing glucose to cellulose. Journal of Biochemistry. 1954, vol. 58, no. 2, pp. 345-352.

20. Yang X.Y., Huang C., Guo H.J., Xiong L., Li Y.Y., Zhang H.R., Chen X.D. Bioconversion of elephant grass (Pennisetum purpureum) acid hydrolysate to bacterial cellulose by Gluconacetobacter xylinus. Journal of Applied Microbiology. 2013, vol. 115, no. 4, pp. 995-1002. http://dx.doi.org/10.1111/jam.12255

21. Mohammadkazemi F., Doosthoseini K., Azin M. Effect of ethanol and medium on bacterial cellulose (BC) production by Gluconacetobacter $x y$ linus (PTCC 1734). Cellulose chemistry and technology. 2015, vol. 49, no. 5-6, pp. 455-462. 
22. Gladysheva E.K., Skiba E.A. Biosynthesis of bacterial cellulose on enzymatic hydrolyzate of oat hull pulp. Izvestiya vuzov. Prikladnaya khimiya i biotekhnologiya. 2017, vol. 7 , no. 1 , pp. 141-147. (In Russian). DOI: 10.21285/2227-2925-2017-7-1-141-147

23. Bassem B.H., Ragauskas A.J. Analyzing cellulose degree of polymerization and its relevancy to cellulosic ethanol. Biofuels Bioproducts and Biorefining. 2011, vol. 5, pp. 215-225. DOI: 10.1002/bbb.269

24. Kashcheyeva E.I., Gladysheva E.K., Skiba E.A., Budaeva V.V. A study of properties and enzymatic hydrolysis of bacterial cellulose. Cellulose. 2019, vol. 26 , issue 4, pp. 2255-2265. DOI: 10.1007/s105 70-018-02242-7

25. Yurkevich D.I., Kutyshenko V.P. Meduzomitset (Chainyi grib): nauchnaya istoriya, sostav, osbennosti fiziologii i metabolizma. Biofizika. 2002, no. 6, pp. 1116-1129. (in Russian).

26. Brandes R., de Souza L., Vanin D.V.F., Carminatti C.A., Oliveira E.M., Antônio R.V., Recouvreux D.O.S. Influence of the Processing Parameters on the Characteristics of Spherical Bacterial Cellulose. Fibers and Polymers. 2018, vol. 19, no. 2, pp. 297-306. DOI: $10.1007 / \mathrm{s} 12221-018-7679-5$

27. Abdelraof M., Hasanin M.S., El -Saied H. Ecofriendly green conversion of potato peel wastes to high productivity bacterial cellulose. Carbohydrate Polymers. 2019, vol. 211, pp. 75-83. https://doi.org/ 10. 1016/j.carbpol.2019.01.095

28. Rangaswamy B.E., Vanitha K.P., Hungund B.S. Microbial Cellulose Production from Bacteria Isolated from Rotten Fruit. International Journal of Polymer
Science. 2015. http://dx.doi.org/10.1155/2015/280784

29. Huang C., Yang X.Y., Xiong L., Guo H.J., Luo J., Wang B., Zhang H.R., Lin X.Q., Chen X.D. Utilization of Corncob Acid Hydrolysate for Bacterial Celulose Production by Gluconacetobacter xylinus. Applied Biochemistry and Biotechnology. 2015, vol. 175, no. 3, pp. 1678-1688. https://doi.org/10.1007/s120 10-014-1407-z

30. Pacheco G., Nogueira C.R., Meneguin A.B., Trovatti E., Silva M.C.C., Machado R.T.A., Ribeiro S.J.L., Filho E.C.S., Barud H.S. Development and characterization of bacterial cellulose produced by cashew tree residues as alternative carbon source. Industrial Crops and Products. 2017, vol. 107, pp. 13-19. http://dx.doi.org/10.1016/j.indcrop.2017.05.026

31. Hassan E.A., Abdelhady H.M., E-Salam S.S.A., Abdullah S.M. The characterization of bacterial cellulose produced by Acetobacter xylinum and Komgataeibacter saccharovorans under optimized fermentation conditions. British Microbiology Research Journal. 2015, vol. 9, no. 3, pp. 1-13. DOI: 10.9734/ BMRJ/2015/18223

32. Tsouko E., Kourmentza C., Ladakis D., Kopsahelis N., Mandala I., Papanikolaou S., Paloukis F., Alves $\mathrm{V}$., Koutinas A. Bacterial cellulose production from industrial waste and by-product streams. International Journal of Molecular Sciences. 2015, vol. 16, no. 7, pp. 14832-14849. https://doi.org/10.1007/s105 70-019-02307-1

33. Cellulose and Cellulose Derivatives. Parts IV-V. Ed. by N.M. Bikales, L. Segal New York: WileyIntersciense, 1971, $510 \mathrm{p}$.

\section{БИБЛИОГРАФИЧЕСКИЙ СПИСОК}

1. Campano C., Balea A., Blanco A., Negro C. Enhancement of the fermentation process and properties of bacterial cellulose: a review // Cellulose. 2016. Vol. 23. P. 57-91. https://doi.org/10.1007/s105 70-015-0802-0

2. Gama M., Dourado F., Bielecki S. Bacterial nanocellulose. From Biotechnology to Bio-Economy. Amsterdam: Elsevier, 2016. 240 p.

3. Ревин В.В., Кленова Н.А., Белоусова 3.П., Редькин Н.А., Тукмаков К.Н., Маркова Ю.А., Сосова Э.Ю. Получение и изучение свойств композитов на основе бактериальной целлюлозы и поли-N, N-диметил-3,4-метиленпирролидиний хлорида // Известия вузов. Прикладная химия и биотехнология. 2017. T. 7. N 1. C. 103-111. DOI: 10.21 285/2227-2925-2017-7-1-103-111

4. Barud H.G., Rosa da Silva R., Barud H.S., Tercjak A., Gutierrez J., Lustri W.R., et al. A multipurpose natural and renewable polymer in medical applications: Bacterial cellulose // Carbohydrate Polymers. 2016. Vol. 153. P. 406-420. https://doi.org/10. 1016/j.carbpol.2016.07.059

5. Mohite B.V., Koli S.H., Patil S.V. Bacterial Cellulose-Based Hydrogels: Synthesis, Properties, and Applications. In: Mondal M. (eds) Cellulose-Based Superabsorbent Hydrogels. Polymers and Polymeric Composites: A Reference Series. Springer, Cham. 2019.
Р. 1255-1276. https://doi.org/10.1007/978-3-319-77830-3 2

6. Suresh S. Biosynthesis and Assemblage of Extracellular Cellulose by Bacteria. In: Hussain C. (eds) Handbook of Environmental Materials Management. Springer, Cham. 2018. P. 1-43. https://doi.org/ 10.1007/978-3-319-58538-3_71-1

7. Shidlovskiy I.P., Shumilova A.A., Shishatskaya E.I., Volova T.G. Properties of Bacterial Cellulose Composites with Silver Nanoparticles // Biophysics. 2018. Vol. 63. No. 4. P. 519-525. https://doi.org/10. $1134 / \mathrm{S} 0006350918040188$

8. Рогожин В.В., Рогожин Ю.В. Влияние анаэробных условий на продуктивность Medusomyces gisevii // Известия вузов. Прикладная химия и биотехнология. 2018. T. 8. N 1. C. 59-66. DOI: 10. 21285/2227-2925-2018-8-1-59-66

9. Gladysheva E.K., Skiba E.A., Zolotukhin V.N., Sakovich G. V. Study of the Conditions for the Biosynthesis of Bacterial Cellulose by the Producer Medusomyces gisevii Sa-12 // Applied Biochemistry and Microbiology. 2018. Vol. 54. No. 2. P. 179-187. DOI: 10.1134 / S0003683818020035

10. Goh W.N., Rosma A., Kaur B., Fazilah A., Karim A.A, Rajeev B. Microstructure and physical properties of microbial cellulose produced during femen tation of black tea broth (kombucha). II // International Food Research Journal. 2012. Vol. 19 (1). P. 153-158. 
11. Krystynowicz A., Czaja W., Wiktorowska-Jezierska A., Gonc M., alves-Mis kiewicz, Turkiewicz M., Bielecki S. Factors affecting the yield and properties of bacterial cellulose // Journal of Industrial Microbiology and Biotechnology. 2002. Vol. 29. No. 4. P. 189-195. https://doi.org/10.1038/sj.jim.7000303

12. Römling U., Galperin M.Y. Bacterial cellulose biosynthesis: Diversity of operons, subunits, products, and functions // Trends in Microbiology. 2015. Vol. 23. P. 545-557. doi:10.1016/j.tim.2015.05.005

13. Borzani W., Souza S.J. Mechanism of the film thickness increasing during the bacterial production of cellulose on non-agitated liquid media // Biotechnology Letters. 1995. Vol. 17. No. 11. P. 1271-1272. https://doi.org/10.1007/BF00128400

14. Cheng K.C., Catchmark J.M., Demirci A. Enhanced production of bacterial cellulose by using a biofilm reactor and its material property analysis // Journal of Biological Engineering. 2009. Vol. 3. P. 12. https://doi.org/10.1186/1754-1611-3-12

15. Stepanov N., Efremenko E. "Deceived" Concentrated Immobilized Cells as Biocatalyst for Intensive Bacterial Cellulose Production from Various Sources // Catalysts. 2018. Vol. 8. No. 1. P. 33. https://doi.org/10.3390/catal8010033

16. Valls C., Pastor F.I.J., Roncero M.B., Vidal T., Diaz P., Martínez J., Valenzuela S.V. Assessing the enzymatic effects of cellulases and LPMO in improving mechanical fibrillation of cotton linters // Biotechnology for Biofuels. 2019. Vol. 12. P. 161. https://doi.org/10.1186/s13068-019-1502-z

17. Zugenmaier P. Crystalline Cellulose and Derivatives: Characterization and Structures, Springer Series in Wood Science. Springer-Verlag Berlin Heidleberg. 2008. 285 p.

18. Shi Q.S., Feng J., LW.R., Zhou G., Chen A.M., Ouyang Y.S., Chen Y.B. Effect of different conditions on the average degree of polymerization of bacterial cellulose produced by Gluconacetobacter Intermedius BC-41 // Cellulose Chemistry and Technology. 2013. Vol. 47. P. 503-508.

19. Hestrin S., Schramm M. Synthesis of cellulose by Acetobacter xylinum: II. Preparation of freeze-dried cells capable of polymerizing glucose to cellulose // Journal of Biochemistry. 1954. Vol. 58. No. 2. P. 345-352.

20. Yang X.Y., Huang C., Guo H.J., Xiong L., L Y.Y., Zhang H.R., Chen X.D. Bioconversion of elephant grass (Pennisetum purpureum) acid hydrolysate to bacterial cellulose by Gluconacetobacter xylinus // Journal of Applied Microbiology. 2013. Vol. 115. No. 4. P. 995-1002. http://dx.doi.org/10.1111/jam.12255

21. Mohammadkazemi F., DoosthoseiniK., Azin M. Effect of ethanol and medium on bacterial cellulose (BC) production by Gluconacetobacter xylinus (PTCC 1734) // Cellulose chemistry and technology. 2015. Vol. 49. No. 5-6. P. 455-462.

22. Гладышева Е.К., Скиба ЕА. Биосинтез бактериальной целлюлозы на ферментативном гидрализате технической целлюлозы из плодовых оболочек овса // Известия вузов. Прикладная хи- мия и биотехнология. 2017. Т. 7. N 1. С. 141-147. DOI: 10.21285/2227-2925-2017-7-1-141-147

23. Bassem B.H., Ragauskas A.J. Analyzing cellulose degree of polymerization and its relevancy to cellulosic ethanol // Biofuels Bioproducts and Biorefining. 2011. Vol. 5. P.215-225. DOI: 10.1002/bbb.269

24. KashcheyevaE.I., GladyshevaE.K., Skiba E.A., Budaeva V.V. A study of properties and enzymatic hydrolysis of bacterial cellulose // Cellulose. 2019. Vol. 26. Issue 4. P. 2255-2265. DOI: 10.1007/s105 70-018-02242-7

25. Юркевич Д.И., Кутышенко В.П. Медузомицет (чайный гриб): научная история, состав, особенности фризиологии и метаболизма // Биофизика. 2002. N 6. С. 1116-1129.

26. Brandes R., de Souza L., Vanin D.V.F., Carminatti C.A., Oliveira E.M., Antônio R.V., Recouvreux D.O.S. Influence of the Processing Parameters on the Characteristics of Spherical Bacterial Cellulose // Fibers and Polymers. 2018. Vol.19. No. 2. P. 297-306. DOI 10.1007/s12221-018-7679-5

27. Abdelraof M., Hasanin M.S., El -Saied H. Ecofriendly green conversion of potato peel wastes to high productivity bacterial cellulose // Carbohydrate Polymers. 2019. Vol. 211. P. 75-83. https://doi.org/10.1016/j.carbpol.2019.01.095

28. RangaswamyB.E., Vanitha K.P., Hungund B.S. Microbial Cellulose Production from Bacteria Isolated from Rotten Fruit // International Journal of Polymer Science. 2015. http://dx.doi.org/10.1155/2015/280784

29. Huang C., Yang X.Y., Xiong L., Guo H.J., Luo J., Wang B., Zhang H.R., Lin X.Q., Chen X.D. Utilization of Corncob Acid Hydrolysate for Bacterial Cellulose Production by Gluconacetobacter xylinus // Applied Biochemistry and Biotechnology. 2015. Vol. 175. No. 3. P. 1678-1688. https://doi.org/10.1007/s 12010-014-1407-z

30. Pacheco G., Nogueira C.R., Meneguin A.B., Trovatti E., Silva M.C.C., Machado R.T.A., Ribeiro S.J.L., Filho E.C.S., Barud H.S. Development and characterization of bacterial cellulose produced by cashew tree residues as alternative carbon source // Industrial Crops and Products. 2017. Vol. 107. P. 1319. http://dx.doi.org/10.1016/j.indcrop.2017.05.026

31. Hassan EA., AbdelhadyH.M., El-Salam S.S.A., Abdullah S.M. The characterization of bacterial cellulose produced by Acetobacter xylinum and Komgataeibacter saccharovorans under optimized fermentation conditions // British Microbiology Research Journal. 2015. Vol. 9. No. 3. P. 1-13. DOI: 10.9734/ BMRJ/2015/18223

32. Tsouko E., Kourmentza C., Ladakis D., Kopsahelis N., Mandala I., Papanikolaou S., Paloukis F., Alves V., Koutinas A. Bacterial cellulose production from industrial waste and by-product streams // International Journal of Molecular Sciences. 2015. Vol. 16. No. 7. P. 14832-14849. https://doi.org/10.10 07/s 10570-019-02307-1

33. Cellulose and Cellulose Derivatives. Parts IV-V / Edited by Bikales N.M. and Segal L. New York: Wiley-Intersciense. 1971, $510 \mathrm{p}$. 


\section{Contribution}

Ekaterina A. Skiba, Olga V. Baibakova, Evgenia K. Gladysheva, Vera V. Budaeva carried out the experimental work, analyzed the experimental results and prepared the text of the manuscript. Ekaterina A. Skiba, Olga V. Baibakova, Evgenia K. Gladysheva, Vera V. Budaeva have equal author's rights and bear equal responsibility for plagiarism.

\section{Conflict of interests}

The authors declare no conflict of interests regarding the publication of this article.

\section{AUTHORS' INDEX}

Ekaterina A. Skiba,

Ph.D. (Engineering), Associate Professor,

Senior Researcher,

Laboratory of Bioconversion,

Institute for Problems of Chemical and Energetic

Technologies of the SB RAS,

$\triangle$ e-mail eas08988@mail.ru

\section{Olga V. Baibakova,}

Ph.D. (Engineering), Junior Researcher,

Laboratory of Bioconversion,

Institute for Problems of Chemical and Energetic

Technologies of the SB RAS,

e-mail: olka_baibakova@mail.ru

Evgenia K. Gladysheva,

Ph.D. (Engineering), Researcher,

Laboratory of Bioconversion,

Institute for Problems of Chemical and Energetic

Technologies of the SB RAS,

e-mail: evg-gladysheva@yandex.ru

\section{Vera V. Budaeva,}

Ph.D. (Chemistry), Associate Professor,

Head of Bioconversion Laboratory,

Institute for Problems of Chemical and Energetic

Technologies of the SB RAS,

e-mail budaeva@ipcet.ru

\section{Критерии авторства}

Скиба Е.А., Байбакова О.В., Гладышева Е.К., Будаева В.В. выполнили экспериментальную работу, на основании полученных результатов провели обобщение и написали рукопись. Скиба Е.А., Байбакова О.В., Гладышева Е.К., Будаева В.В. имеют на статью равные авторские права и несут равную ответственность за плагиат.

\section{Конфликт интересов}

Авторы заявляют об отсутствии конфликта интересов.

\section{СВЕДЕНИЯ ОБ АВТОРАХ}

Скиба Екатерина Анатольевна, к.т.н., доцент, старший научный сотрудник лаборатории биоконверсии,

Институт проблем химико-энергетических технологий СО РАН,

$\bowtie$ e-mail: eas08988@mail.ru

\section{Байбакова Ольга Владимировна,} к.Т.н., младший научный сотрудник лаборатории биоконверсии,

Институт проблем химико-энергетических технологий СО РАН,

e-mail: olka_baibakova@mail.ru

Гладышева Евгения Константиновна, к.т.н., научный сотрудник лаборатории биоконверсии, Институт проблем химико-энергетических технологий СО РАН,

e-mail: evg-gladysheva@yandex.ru

\section{Будаева Вера Владимировна,}

к.Х.н., доцент, заведующая

лабораторией биоконверсии,

Институт проблем химико-энергетических технологий СО РАН,

e-mail: budaeva@ipcet.ru 